Saudi Journal of Business and Management Studies

Abbreviated Key Title: Saudi J Bus Manag Stud

ISSN 2415-6663 (Print) |ISSN 2415-6671 (Online)

Scholars Middle East Publishers, Dubai, United Arab Emirates

Journal homepage: https://saudijournals.com

Original Research Article

\title{
Effect of COVID 19 Pandemic on Healthcare Workers at Jawahar Lal Nehru Medical College Hospital: A Tertiary Care Center in Aligarh, India
}

Shiraz Khan ${ }^{1 *}$, Afzal Anees ${ }^{2}$, Asif Akhtar ${ }^{3}$, Feza Tabassum Azmi ${ }^{4}$

1, 3, 4 Department of Business Administration, Aligarh Muslim University, Aligarh, India

${ }^{2}$ Department of Surgery, Jawahar Lal Nehru Medical College, Aligarh, India

DOI: $10.36348 /$ sjbms.2021.v06i01.002

| Received: 06.01.2021 | Accepted: 18.01.2021 | Published: 19.01.2021

*Corresponding author: Shiraz Khan

\section{Abstract}

As Jawaharlal Nehru Medical College faced the unprecedented challenges of Covid 19, it had put its entire thrust towards providing optimal care to Covid19 patients, by modulating its existing health care system, and the heroes that work therein. Sixty health care staff that were questioned for their varied responses during this project, showed a commendable commitment despite facing some shortcomings and being busy in a totally new work culture. It was also noted during this project that the administration at Jawaharlal Nehru Medical College had committed itself to facing this new health challenge with a clinical resiliency from its junior/ senior doctors and a solid support of the nursing and technical health care staff, who answered the call whenever the hospital needed them.

Keywords: Covid 19 pandemic, health care workers, resident doctors, nursing staff member.

Copyright () 2021 The Author(s): This is an open-access article distributed under the terms of the Creative Commons Attribution 4.0 International License (CC BY-NC 4.0) which permits unrestricted use, distribution, and reproduction in any medium for non-commercial use provided the original author and source are credited.

\section{INTRODUCTION}

Jawaharlal Nehru Medical College at Aligarh in India is an advanced tertiary care center with approximately 1269-bedded hospital having all major medical specialties. During COVID-19 pandemic, Jawaharlal Nehru Medical College undertook a coordinated and multidisciplinary approach between doctors, nurses and technicians within its existing infrastructure towards infection containment and optimal care of these patients.

The hospital claims that it harnessed all its resources towards establishment of an 80-bedded COVID-19 ward with dedicated team of resident doctors, staff nurses and paramedical staff in an 8hourly shift. Each member of the health care team attending to COVID-19 patients was given elaborate education on various aspects of patient management prior to their duty assignment. The hospital diverted its funds from non-essential areas and purchased 10 ventilators, a dialysis machine and lay fresh network of round the clock piped oxygen supply to these patients besides upgrading its laboratories to meet all investigative challenges of this pandemic. Internal communication between frontline health care workers and senior faculty members and administrators takes place through a $24 \times 7$ videoconferencing facility via a state of art command center set up in the administrative block of the college. Further, the hospital claims that any grievance of health care workers, including their psychological stress and demanding duty hours, or optimal care of the patients or their relative is attended by taking appropriate corrective steps.

The aim of this prospective project was to include 60 resident doctors and staff nurses and to evaluate their satisfaction level of the above claims through easy to understand questionnaire/statements.

\section{METHODS}

This project was undertaken after due approval from the administration of Jawahar Lal Nehru Medical College Hospital and Department of Business Administration of Aligarh Muslim University, Aligarh in India. This project was a cross-sectional study wherein the data was collected from 60 health care workers (30 resident doctors and 30 staff nurses) 
Shiraz Khan et al., Saudi J Bus Manag Stud, Jan, 2021; 6(1): 10-14

involved in COVID-19 areas of the hospital between a brief period of ten days from $2^{\text {nd }}$ to $12^{\text {th }}$ August 2020 . To include 30 respondents in each group was arrived as per Creswell and Poth [1] who advocated that a sample size between 20-30 participants for qualitative data collection was appropriate.

The participation of resident doctors and nurses at Jawaharlal Nehru Medical College in this project was purely of their free choice with no use of financial benefits or coerciveness. Only those resident doctors and staff nurses were included in this project for questionnaire who had worked with Covid-19 patients for over a month.

Furthermore, they were advised to tick mark only one option in the box given in front of each questionnaire/statement. Their options could be: Strongly Disagree (1), Disagree (2), Neutral (3), Agree (4), Strongly Agree (5)]. Participants were requested to tick mark their answers in the boxes provided.

The questionnaires/statements were arranged under four areas of concern. They included:

A. Issues related to Human Resources.

B. Psycho-social issues (Mental Wellbeing).

C. Technical issues.

D. Hospital functioning issues.

Questions under each issue have been highlighted in Tables 1-4. Response to each question has been analyzed statistically.

\section{STATISTICS}

Since we had two groups (Resident doctors and Staff nurses) and we analyzed five-point Likert data, both the 2-sample t-test and Chi square test have nearly equivalent type I error rates and power, These results are consistent across group sizes of 10, 30, and up to 200 . We have therefore analyzed data collected from our respondents (Resident doctors \& Staff nurses) using the descriptive statistical tool i.e. independent sample t-test to compare the differences in responses of resident doctors and staff nurses. $\mathrm{P}<0.05$ has been considered statistically significant difference.

\section{RESULTS}

As seen from Table 1, both the nursing staff members and the resident doctors acknowledged that they had to adapt to the new working norms during Covid-19 pandemic. However, the perception differed significantly in the two groups. Resident doctors strongly agreed that their clinical work demanded new adaptations as compared to fewer nursing staff members with similar response $(\mathrm{P}=0.013)$.

Similarly both the resident doctors and nursing staff members disagreed with the hospital administration's claim that the doctor/patient ratio is adequate with respect to patient load but their response showed qualitative difference between strongly disagree/ disagree significantly $(\mathrm{p}=0.004)$. On the contrary, the response of resident doctors and staff nurses on disagreement to nurses/patient ratio was identical. Response to all other questions on human resource issue was nearly identical amongst resident doctors and staff nurses $(\mathrm{P}>0.05)$ without any clear response of agreement or disagreement.

Response of resident doctors and nursing staff members were nearly identical on the psychosocial issues including mental wellbeing. There was no uniformity in their agreement or disagreement to the psychosocial questions posed to them (Table 2).

The response of resident doctors and staff nurses to technical issue while working in the hospital during Covid-19 pandemic was largely identical (Table 3). Though not reaching statistically significant difference to the utility of 'Virtual Rounds' through a dedicated 'Control Room' in patient management, larger number of resident doctors approved it and considered it useful.

As can be seen from Table 4, both the resident doctors and nursing staff members differed significantly in their response to hospital functioning during Covid 19 pandemic in particular to adequate supply of sanitizers, masks and other protective equipment for patients in COVID ward $(\mathrm{P}=0.04)$. In addition, the nursing staff members agreed/strongly agreed that hospital staff members regularly updated the attendants of Covid 19 patients in a timely manner but the resident doctors differed significantly on this issue $(\mathrm{P}=0.020)$. 
Shiraz Khan et al., Saudi J Bus Manag Stud, Jan, 2021; 6(1): 10-14

Table-1: Showing response of resident doctors and staff nurses towards human resource issues during Covid 19 pandemic

\begin{tabular}{|c|c|c|c|c|c|c|c|}
\hline Questions & HCW & $\begin{array}{l}\text { Strongly } \\
\text { Disagree }\end{array}$ & Disagree & Neutral & Agree & $\begin{array}{l}\text { Strongly } \\
\text { agree }\end{array}$ & P-Value \\
\hline \multirow{2}{*}{$\begin{array}{l}\text { 1. I need to adapt to changes in } \\
\text { nature of clinical work during } \\
\text { this pandemic. }\end{array}$} & $\begin{array}{l}\text { Resident } \\
\text { Doctors }\end{array}$ & 0 & 3 & 2 & 9 & 16 & \multirow[t]{2}{*}{0.013} \\
\hline & Staff Nurses & 0 & 1 & 10 & 16 & 3 & \\
\hline \multirow{2}{*}{$\begin{array}{l}\text { 2. I believe doctor/patient ratio } \\
\text { is adequate in our hospital with } \\
\text { respect to patient load during } \\
\text { Covid } 19 \text { pandemic. }\end{array}$} & $\begin{array}{l}\text { Resident } \\
\text { Doctors }\end{array}$ & 6 & 12 & 8 & 1 & 3 & \multirow[t]{2}{*}{0.004} \\
\hline & Staff Nurses & 14 & 13 & 2 & 1 & 0 & \\
\hline \multirow[t]{2}{*}{$\begin{array}{l}\text { 3. I believe nurses/patient ratio } \\
\text { is adequate to patient load }\end{array}$} & $\begin{array}{l}\text { Resident } \\
\text { Doctors }\end{array}$ & 9 & 14 & 4 & 2 & 1 & \multirow[t]{2}{*}{0.254} \\
\hline & Staff Nurses & 11 & 15 & 3 & 1 & 0 & \\
\hline \multirow{2}{*}{$\begin{array}{l}\text { 4. Senior faculty members and } \\
\text { colleagues are appreciating my } \\
\text { hard sincere efforts. }\end{array}$} & $\begin{array}{l}\text { Resident } \\
\text { Doctors }\end{array}$ & 6 & 4 & 8 & 6 & 5 & \multirow[t]{2}{*}{0.562} \\
\hline & Staff Nurses & 8 & 0 & 14 & 6 & 2 & \\
\hline \multirow[t]{2}{*}{$\begin{array}{l}\text { 5. My stamina is affected } \\
\text { while wearing PPE. }\end{array}$} & $\begin{array}{l}\text { Resident } \\
\text { Doctors }\end{array}$ & 2 & 1 & 5 & 15 & 7 & \multirow[t]{2}{*}{0.335} \\
\hline & Staff Nurses & 0 & 3 & 9 & 16 & 2 & \\
\hline \multirow{2}{*}{$\begin{array}{l}\text { 6. There is enough PPE } \\
\text { available for healthcare } \\
\text { professionals }\end{array}$} & $\begin{array}{l}\text { Resident } \\
\text { Doctors }\end{array}$ & 4 & 2 & 12 & 8 & 4 & \multirow[t]{2}{*}{0.848} \\
\hline & Staff Nurses & 6 & 3 & 6 & 7 & 8 & \\
\hline \multirow{2}{*}{$\begin{array}{l}\text { 7. I am updated on the latest } \\
\text { treatment guidelines for Covid } \\
-19 \text { virus. }\end{array}$} & $\begin{array}{l}\text { Resident } \\
\text { Doctors }\end{array}$ & 0 & 2 & 8 & 13 & 7 & \multirow[t]{2}{*}{0.765} \\
\hline & Staff Nurses & 1 & 0 & 6 & 17 & 6 & \\
\hline
\end{tabular}

HCW: Health Care Workers

Table-2: Showing response of resident doctors and staff nurse in relation to Psycho-social issues (Mental Wellbeing) while at work during Covid 19 pandemic.

\begin{tabular}{|c|c|c|c|c|c|c|c|}
\hline Question & HCW & $\begin{array}{l}\text { Strongly } \\
\text { Disagree }\end{array}$ & Disagree & Neutral & Agree & $\begin{array}{l}\text { Strongly } \\
\text { agree }\end{array}$ & P-Value \\
\hline \multirow{2}{*}{$\begin{array}{l}\text { 1. I am well respected as } \\
\text { Corona warrior in my } \\
\text { society \& area of } \\
\text { residence. }\end{array}$} & $\begin{array}{l}\text { Resident } \\
\text { Doctors }\end{array}$ & 1 & 4 & 7 & 9 & 9 & \multirow[t]{2}{*}{0.361} \\
\hline & Staff Nurses & 0 & 1 & 18 & 7 & 4 & \\
\hline \multirow{2}{*}{$\begin{array}{l}\text { 2. My duty as a Corona } \\
\text { healthcare professional is } \\
\text { affecting my social life. }\end{array}$} & $\begin{array}{l}\text { Resident } \\
\text { Doctors }\end{array}$ & 5 & 3 & 5 & 14 & 3 & \multirow[t]{2}{*}{0.392} \\
\hline & Staff Nurses & 7 & 4 & 8 & 6 & 5 & \\
\hline \multirow{2}{*}{$\begin{array}{l}\text { 3. I am getting sound } \\
\text { sleep in my off-duty } \\
\text { hours. }\end{array}$} & $\begin{array}{l}\text { Resident } \\
\text { Doctors }\end{array}$ & 6 & 6 & 4 & 6 & 7 & \multirow[t]{2}{*}{0.205} \\
\hline & Staff Nurses & 5 & 9 & 8 & 8 & 0 & \\
\hline \multirow{2}{*}{$\begin{array}{l}\text { 4. I have an } \\
\text { apprehension of } \\
\text { contracting COVID-19 } \\
\text { while performing my } \\
\text { duties. }\end{array}$} & $\begin{array}{l}\text { Resident } \\
\text { Doctors }\end{array}$ & 7 & 4 & 7 & 8 & 4 & \multirow[t]{2}{*}{0.995} \\
\hline & Staff Nurses & 6 & 5 & 8 & 5 & 5 & \\
\hline \multirow{2}{*}{$\begin{array}{l}\text { 5. There are incidences } \\
\text { of conflicts among } \\
\text { healthcare professionals. }\end{array}$} & $\begin{array}{l}\text { Resident } \\
\text { Doctors }\end{array}$ & 7 & 9 & 6 & 6 & 2 & \multirow[t]{2}{*}{1.000} \\
\hline & Staff Nurses & 2 & 13 & 12 & 2 & 1 & \\
\hline
\end{tabular}

HCW: Health Care Workers 
Shiraz Khan et al., Saudi J Bus Manag Stud, Jan, 2021; 6(1): 10-14

Table-3: Showing response of resident doctors and staff nurses to technical issue while working in the hospital during Covid-19 pandemic.

\begin{tabular}{|c|c|c|c|c|c|c|c|}
\hline Question & HCW & $\begin{array}{l}\text { Strongly } \\
\text { Disagree }\end{array}$ & Disagree & Neutral & Agree & $\begin{array}{l}\text { Strongly } \\
\text { agree }\end{array}$ & P-Value \\
\hline \multirow{2}{*}{$\begin{array}{l}\text { 1. There is comprehensive } \\
\text { COVID-19 testing facility at } \\
\text { Jawaharlal Nehru Medical } \\
\text { College Hospital. }\end{array}$} & $\begin{array}{l}\text { Resident } \\
\text { Doctors }\end{array}$ & 0 & 2 & 8 & 11 & 8 & \multirow[t]{2}{*}{0.306} \\
\hline & Staff Nurses & 1 & 1 & 9 & 15 & 3 & \\
\hline \multirow{2}{*}{$\begin{array}{l}\text { 2. There is adequate } \\
\text { availability of ventilators as } \\
\text { per requirements. }\end{array}$} & $\begin{array}{l}\text { Resident } \\
\text { Doctors }\end{array}$ & 12 & 10 & 4 & 4 & 0 & \multirow[t]{2}{*}{0.197} \\
\hline & Staff Nurses & 7 & 11 & 6 & 3 & 2 & \\
\hline \multirow{2}{*}{$\begin{array}{l}\text { 3. Virtual Rounds' through } \\
\text { Control Room are helping in } \\
\text { patient management. }\end{array}$} & $\begin{array}{l}\text { Resident } \\
\text { Doctors }\end{array}$ & 5 & 6 & 12 & 6 & 1 & \multirow[t]{2}{*}{0.074} \\
\hline & Staff Nurses & 1 & 2 & 15 & 9 & 0 & \\
\hline \multirow{2}{*}{$\begin{array}{l}\text { 4. There is adequate number } \\
\text { of bed-side monitors for } \\
\text { managing critically ill- } \\
\text { patients. }\end{array}$} & $\begin{array}{l}\text { Resident } \\
\text { Doctors }\end{array}$ & 11 & 8 & 5 & 5 & 1 & \multirow[t]{2}{*}{0.341} \\
\hline & Staff Nurses & 7 & 11 & 1 & 8 & 2 & \\
\hline \multirow{2}{*}{$\begin{array}{l}\text { 5. Infra-red temperature } \\
\text { recording device is available } \\
\text { in wards and other locations. }\end{array}$} & $\begin{array}{l}\text { Resident } \\
\text { Doctors }\end{array}$ & 12 & 14 & 1 & 3 & 0 & \multirow[t]{2}{*}{0.397} \\
\hline & Staff Nurses & 10 & 13 & 3 & 0 & 3 & \\
\hline
\end{tabular}

HCW: Health Care Workers

Table-4: Showing expression of satisfaction by resident doctors and staff nurses towards hospital functioning during Covid 19 pandemic.

\begin{tabular}{|c|c|c|c|c|c|c|c|}
\hline Question & HCW & $\begin{array}{l}\text { Strongly } \\
\text { Disagree }\end{array}$ & Disagree & Neutral & Agree & $\begin{array}{l}\text { Strongly } \\
\text { agree }\end{array}$ & P-Value \\
\hline \multirow{2}{*}{$\begin{array}{l}\text { 1. There is a 24-hour duty } \\
\text { schedule present for } \\
\text { COVID19 ward. }\end{array}$} & $\begin{array}{l}\text { Resident } \\
\text { Doctors }\end{array}$ & 5 & 2 & 5 & 7 & 11 & \multirow[t]{2}{*}{0.600} \\
\hline & Staff Nurses & 4 & 0 & 12 & 7 & 6 & \\
\hline \multirow{2}{*}{$\begin{array}{l}\text { 2. I get timely investigation } \\
\text { reports of COVID Isolation } \\
\text { ward patients. }\end{array}$} & $\begin{array}{l}\text { Resident } \\
\text { Doctors }\end{array}$ & 8 & 10 & 4 & 3 & 5 & \multirow[t]{2}{*}{0.132} \\
\hline & Staff Nurses & 3 & 7 & 10 & 4 & 6 & \\
\hline \multirow{2}{*}{$\begin{array}{l}\text { 3. There is adequate supply } \\
\text { of sanitizers, masks and other } \\
\text { protective equipment for } \\
\text { Patients in COVID ward. }\end{array}$} & $\begin{array}{l}\text { Resident } \\
\text { Doctors }\end{array}$ & 6 & 10 & 8 & 2 & 4 & \multirow[t]{2}{*}{0.046} \\
\hline & Staff Nurses & 2 & 8 & 6 & 8 & 6 & \\
\hline \multirow{2}{*}{$\begin{array}{l}\text { 4. There is optimal } \\
\text { management of patients in } \\
\text { Covid-19 Isolation wards. }\end{array}$} & $\begin{array}{l}\text { Resident } \\
\text { Doctors }\end{array}$ & 2 & 10 & 7 & 8 & 3 & \multirow[t]{2}{*}{0.143} \\
\hline & Staff Nurses & 0 & 5 & 12 & 9 & 4 & \\
\hline \multirow{2}{*}{$\begin{array}{l}\text { 5. The hospital has facility to } \\
\text { accommodate attendants } \\
\text { accompanying Covid } 19 \\
\text { patients. }\end{array}$} & $\begin{array}{l}\text { Resident } \\
\text { Doctors }\end{array}$ & 1 & 8 & 12 & 2 & 5 & \multirow[t]{2}{*}{0.162} \\
\hline & Staff Nurses & 0 & 2 & 14 & 8 & 3 & \\
\hline \multirow{2}{*}{$\begin{array}{l}\text { 6. Hospital staff members } \\
\text { update attendants of Covid } \\
19 \text { patients in a timely } \\
\text { manner. }\end{array}$} & $\begin{array}{l}\text { Resident } \\
\text { Doctors }\end{array}$ & 4 & 7 & 8 & 5 & 5 & \multirow[t]{2}{*}{0.020} \\
\hline & Staff Nurses & 0 & 0 & 13 & 15 & 2 & \\
\hline
\end{tabular}

HCW: Health Care Workers

\section{DISCUSSION}

Jawahar Lal Nehru Medical College hospital has stepped up its effort, in heroic and unprecedented ways, to meet the challenges of COVID-19. As outbreaks have occurred in Aligarh region of India infecting nearly ten thousand people, this hospital has ramped up its facilities in an effort to treat and save lives and minimize the virus' spread. This includes establishing dedicated Covid ward to isolate and treat patients with the disease while safeguarding the health of other patients and hospital staff.

The health care staff that were questioned for their varied responses during this survey, showed a commendable commitment despite facing some shortcomings while being busy in a totally new work culture. 
Shiraz Khan et al., Saudi J Bus Manag Stud, Jan, 2021; 6(1): 10-14

Doctors, nurses, and other health care workers have met the COVID 19 challenge at Jawahar Lal Nehru Medical College with heroic efforts, but not without facing psycho-social and mental wellbeing issues as well as stress of working in a virus prone environment. This is in agreement with the universal impact of Covid 19 pandemic on health care workers physically and psychologically [2].

A study from Singapore showed that healthcare workers caring for patients with Covid 19 reported anxiety, depression, stress and even suicidal tendencies [3]. Elsewhere, healthcare professionals reported being anxious about having to self-isolate, quarantine or becoming ill [4]. Fortunately, we did not note any such adverse remarks in our survey by resident doctors and nursing staff members working at Jawahar Lal Nehru Medical College. This could be attributed to the administration getting regular feedbacks from frontline health care workers. If there are any issues to be addressed, they take appropriate actions. The health care workers on COVID-19 duty are provided with a dedicated mobile phone for seeking any advice from senior faculty members, as well as to express their grievances while on duty. This is in addition to the hospital landline phones. They can use this facility to call any member of administration, any time $24 X 7$. All attempts are made to deal with the grievance immediately. This is possible as a team is always present to attend to these issues and streamline any inefficiency, including psychological care.

Hospitals across the world have experienced inadequate supplies of PPE \& non-PPE medical supplies and equipment $[5,6]$. Contrary to expectation, resident doctors and staff nurses at Jawahar Lal Nehru Medical College agree that there is a comprehensive Covid 19 testing facility and protective gears in the hospital. However, both feel that there is a deficiency in ventilators and monitors in the hospital for Covid 19 patients.

This project had a few limitations. First, this project did not assess the impact of continued stress and revenue losses or increased costs beyond August 5. Any future waves of Covid-19 infections may result in increased levels of stress and additional net losses. Second, this project did not assess the long-term stress on health care workers at Jawahar Lal Nehru Medical College, or systemic financial impacts of the Covid 19 pandemic on this hospital. Lastly, these estimates likely under-represent the full impact of human stress at Jawahar Lal Nehru Medical College, Aligarh as the sample size was relatively small.

In conclusion, the health care staff of Jawahar Lal Nehru Medical College at Aligarh in India who were questioned for their varied responses during this project, showed a commendable commitment despite facing some shortcomings and being busy in a totally new work culture.

\section{REFERENCES}

1. Creswell, J., Poth, C.N. (1998). Qualitative inquiry and research design: Choosing among five traditions. $4^{\text {th }}$ Edition.Thousand Oaks, CA: SAGE publications.

2. How to protect health workers now: WHO COVID-19 briefing" .(2020). World Economic Forum. Retrieved 13 May 2020.

3. Tan, B. Y., Chew, N. W., Lee, G. K., Jing, M., Goh, Y., Yeo, L. L., ... \& Sharma, V. K. (2020). Psychological impact of the COVID-19 pandemic on health care workers in Singapore. Annals of Internal Medicine.

4. Brooks, S. K., Webster, R. K., Smith, L. E., Woodland, L., Wessely, S., Greenberg, N., \& Rubin, G. J. (2020). The psychological impact of quarantine and how to reduce it: rapid review of the evidence. The Lancet.

5. Wingfield, T., \& Taegtmeyer, M. (2020). Healthcare workers and coronavirus: behind the stiff upper lip we are highly vulnerable. https://theconversation. com/uk.

6. "Begging for Thermometers, Body Bags, and Gowns. (2020). U.S. Health Care Workers Are Dangerously Ill-Equipped to Fight COVID19". Time. Retrieved 13 May 2020. 